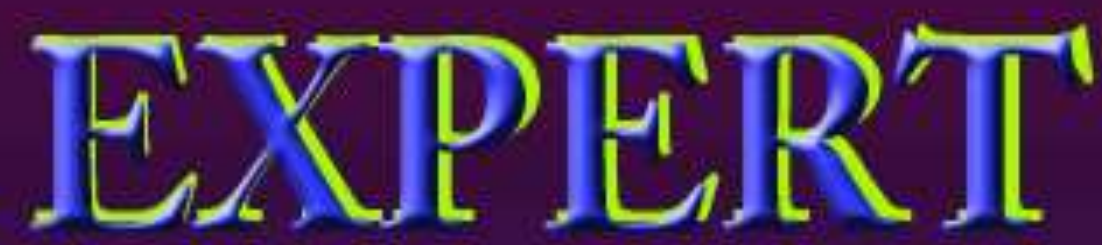

Jurnal Sistem Informasi

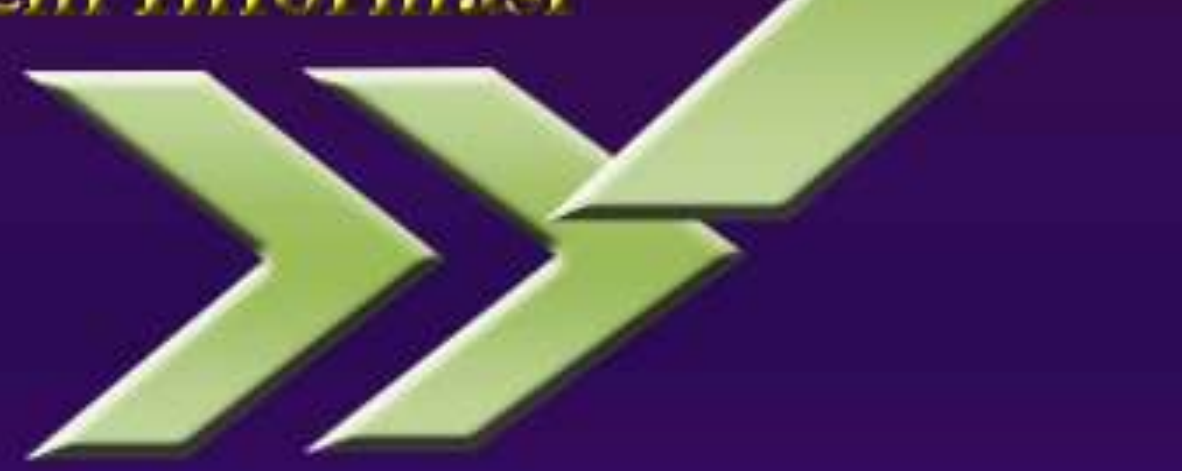

PENGGUNAAN METODE ANALISIS HISTORIS UNTUK MENENTUKAN ANGGARAN PRODUKSI.

Dedi Darwis, Tika Yusiana

PROTOTYPE SISTEM PENUNJANG KEPUTUSAN PENENTUAN KELAYAKAN GUDANG PENERIMAAN PUPUK PUSRI DENGAN METODE SIMPLE ADDITIVE WEIGTHING (SAW).

Sushanty Saleh, Toni Fedrik

ANALISIS SISTEM INFORMASI PENGAWAS KEAMANAN DAN KESEHATAN MAKAN PADA DINAS KESEHATAN KOTA BANDAR LAMPUNG.

Deppi Linda

RANCANG BANGUN APLIKASI VISUALISASI KAMUS BAHASA LAMPUNG BERBASIS ANDROID.

Indera

APLIKASI KOMITE SEKOLAH BERBASIS SMS NOTIFIKASI UNTUK ADMINISTRASI PEMBAYARAN KOMITE.

Fenty Ariani

PEMETAAN SEBARAN MENARA TELEKOMUNIKASI SELULER BERSAMA BERBASIS GIS (GEOGRAPHIC INFORMATION SYSTEM) DI WILAYAH KOTA BANDARL AMPUNG.

TaqwanThamrin, Wiwin Susanty

ISSN : 2088-5555 Write Tn Be Experte 


\section{Expert}

Jurnal Manajemen Sistem Informasi Dan Teknologi

Volume 06, Nomor 02, Desember 2016

\begin{tabular}{|l|c|}
\hline Judul & Hal \\
\hline $\begin{array}{l}\text { PENGGUNAAN METODE ANALISIS HISTORIS UNTUK } \\
\text { MENENTUKAN ANGGARAN PRODUKSI. }\end{array}$ & $42-51$ \\
\hline $\begin{array}{l}\text { PROTOTYPE SISTEM PENUNJANG KEPUTUSAN } \\
\text { PENENTUAN KELAYAKAN GUDANG PENERIMAAN } \\
\text { PUPUK PUSRI DENGAN METODE SIMPLE ADDITIVE } \\
\text { WEIGTHING }(\text { SAW). }\end{array}$ & $52-59$ \\
\hline $\begin{array}{l}\text { ANALISIS SISTEM INFORMASI PENGAWAS } \\
\text { KEAMANAN DAN KESEHATAN MAKAN } \\
\text { PADA DINAS KESEHATAN KOTA BANDAR LAMPUNG. }\end{array}$ & $60-68$ \\
\hline $\begin{array}{l}\text { RANCANG BANGUN APLIKASI VISUALISASI KAMUS } \\
\text { BAHASA LAMPUNG BERBASIS ANDROID. }\end{array}$ & $69-75$ \\
\hline $\begin{array}{l}\text { APLIKASI KOMITE SEKOLAH BERBASIS SMS } \\
\text { NOTIFIKASI UNTUK ADMINISTRASI PEMBAYARAN } \\
\text { KOMITE. }\end{array}$ & $76-84$ \\
\hline $\begin{array}{l}\text { PEMETAAN SEBARAN MENARA TELEKOMUNIKASI } \\
\text { SELULER BERSAMA BERBASIS GIS (GEOGRAPHIC } \\
\text { INFORMATION SYSTEM) DI WILAYAH KOTA BANDAR } \\
\text { LAMPUNG. }\end{array}$ & $85-92$ \\
\hline
\end{tabular}

Fakultas Ilmu Komputer

Universitas Bandar Lampung

\begin{tabular}{|c|l|l|c|c|}
\hline JMSIT & Volume 06 & Nomor 02 & $\begin{array}{c}\text { Lampung } \\
\text { Desember 2016 }\end{array}$ & $\begin{array}{c}\text { ISSN } \\
2088-5555\end{array}$ \\
\hline
\end{tabular}




\section{TIM PENYUNTING}

Ketua Tim Redaksi:

Taqwan Thamrin,ST,M.Sc

Penyunting Ahli

Mustofa Usman, Ph.D

Dr.Iing Lukman,M.Sc.

Usman Rizal, ST.,MMSI

\section{Penyunting:}

Fenty Ariani,S.Kom,M.Kom

Wiwin Susanty,S.Kom,M.Kom

Ayu Kartika Puspa,S.Kom,M.TI

Erlangga,S.Kom,M.Kom

Pelaksana Teknis:

Prima Khoirul Aini, S.Kom

Alamat Penerbit/Redaksi:

Pusat Studi Teknologi Informasi

Fakultas Ilmu Komputer

Universitas Bandar Lampung

Gedung Business Center Lt. 2

Jl,Zainal Abidin Pagar Alam No.26

Bandar Lampung

Telp.0721 - 774626

Email: Journal.expert@ubl.ac.id 


\title{
RANCANG BANGUN APLIKASI VISUALISASI KAMUS BAHASA LAMPUNG BERBASIS ANDROID
}

\author{
Indera \\ Program Studi Sistem Informasi \\ Fakultas Ilmu Komputer \\ Institut Informatika dan Bisnis Darmajaya \\ Jl. Z.A. Pagar Alam No. 93, Bandar Lampung - Indonesia 35142 \\ Telp. (0721) 787214 Fax. (0721) 700261 \\ E-mail : inderadarmajaya@gmail.com \\ Handphone : 081271952125
}

\begin{abstract}
ABSTRAK
Masyarakat lampung saat ini diketahui masih sangat minim pengetahuannya dalam memahami bahasa lampung itu sendiri. Dari data yang diperoleh pada kantor bahasa Provinsi Lampung tahun 2008 diketahui bahwa jumlah penutur bahasa lampung sekitar 11,92\%, dimana 88,08\% tidak dapat berbahasa lampung. Oleh karena itu pemerintah daerah lampung melakukan berbagai upaya untuk melestarikan budaya lampung salah satunya dengan melestarikan bahasa daerah lampung yang hampir punahHal ini terbukti dengan adanya komitmen pemerintah yang tertuang dalam Peraturan Daerah Nomor 8 Tahun 2008 tentang Pemeliharaan Budaya Lampung. Di situ disebutkan bahwa"bahasa dan aksara Lampung sebagai unsur kekayaan budaya wajib dikembangkan.Hal ini dilakukan karena tanpa upaya yang sistematis besar kemungkinan bahasa daerah lampung akan punah. Punahnya bahasa daerah maka berarti akan punah pula budaya daerah yang bersangkutan. Tahapan yang akan dilakukan dalam penelitian ini terdiri dari : tahap analisis, , perancangan, pembuatan perangkat lunak dan testing. Aplikasi yang dihasilkan memiliki kemampuan untuk menterjemahkan kata dari dua sumber input, yaitu kata bersumber bahasa Indonesia dan sumber bahasa Lampung yang selanjutnya akan dierjemahkan kedalam kata bahasa lampung dan Indonesia. Selain dalam bentuk kata, visualisasi kata hasil terjemahan juga dapat ditampilkan.Adanya Kamus bahasa lampung berbasis android ini diharapkan dapat membantu program pemerintah dalam upaya peningkatan kemampuan bahasa lampung diberbagai kalangan masyarakat propinsi lampung baik insan akademisi maupun masyarakat umum. Dengan demikian upaya pelestarian bahasa daerah lampung dapat dicapai.
\end{abstract}

Kata Kunci: Bahasa,aksara, aplikasi, visualisasi

\section{PENDAHULUAN 1.1 Latar Belakang}

"Bhineka Tunggal Ika" adalah selogan bangsa Indonesia yang tak lekang oleh waktu. Beraneka ragam budaya yang ada akan tetapi tetap satu itulah makna yang terkandung dari selogan tersebut. Aneka ragam budaya yang ada merupakan asset bangsa Indonesia yang mesti dijaga kelestariannya. Bermacam-macam upaya dilakukan untuk menjaga kelestarian budaya tersebut. Upaya ini tidak hanya dilakukan oleh para tokoh adat, tetapi juga dilakukan oleh pemerintah daerah. Tokoh adat dan pemerintah daerah bekerja sama melalui berbagai upaya untuk menjaga kelestarian budaya daerah maupun menghidupkan kembali budaya yang hampir punah, baik adat istiadat, tari-tarian daerah, pakaian, benda-benda bersejarah, dan yang tak kalah penting adalah bahasa daerah.

Pada kenyataannya berdasarkan data Kantor Bahasa Provinsi Lampung tahun 2008, menyebutkan bahwa jumlah penutur Bahasa Lampung di kisaran angka $11.92 \%$.
Dengan asumsi bahwa $88.08 \%$ masyarakatLampung tidak bisa ber-Bahasa Lampung. Berkaitan dengan hal tersebut Pemerintah daerah Lampung melakukan berbagai upaya dalam melestarikan budaya termasuk bahasa daerahnya yang sangat beragam yang hampir punah .Hal ini terbukti dengan adanya komitmen pemerintah yang tertuang dalam Peraturan Daerah Nomor 8 Tahun 2008 tentang Pemeliharaan Budaya Lampung. Di situ disebutkan bahwa" bahasa dan aksara Lampung sebagai unsur kekayaanbudaya wajib dikembangkan.

Peraturan daerah tersebut diperkuat lagi oleh Peraturan Gubernur Lampung No. 4 Tahun 2011 tentang Pengembangan, Pelestarian Bahasa Lampung dan Aksara Lampung. Meskipun demikian perundangan-undangan tidak aka nada manfaatnya tanpa adanya upaya-upaya yang sistematis dan strategis dari pemerintah dan perguruan tinggi dengan didukung oleh sastrawan, seniman, budayawan, dunia usaha, dan masyarakat luas (Lampost.co.id,).

Implementasi dari komitmen tersebut pemerintah mewajibkan pelajaran bahasa lampung diajarkan disekolah-sekolah (PERDA PROP Lampung No.2 
tahun 2008 Pasal 8 point (e)Pengenalan dan pengajaran bahasa dan aksara Lampung mulai jenjang kanakkanak, sekolah dasar dan sekolah menengah yang pelaksanaannya disesuaikan dengan ketentuan yang diberlakukan di daerah, kondisi dan keperluan. Selain itu wacana Pemerintah Provinsi Lampung dan kabupaten-kabupaten di Provinsi

\subsection{Rumusan Masalah}

Berdasarkan latar belakang diatas, maka perumusan masalah pada penelitian ini adalah :"Bagaimana mengimplementasikan Sistem Operasi Android dalam membangun aplikasi kamus bahasa lampung yang dilengkapi dengan suara (cara mengucapkannya? “.

\subsection{Batasan Masalah}

Batasan masalah dalam penelitian ini yaitu aplikasi kamus bahasa lampung berbasis android khusus pada lampung sungkai,pubian.

\subsection{Tujuan dan Manfaat Penelitian \\ 1.4.1 Tujuan Penelitian}

a. Untuk Mengetahui aplikasi kamus bahasa lampung berbasis android disertai visualisasinya.

b. Untuk Mengetahui dialek-dialek yang ada di Provinsi Lampung guna meningkatkan kemampuan berbahasa daerah bagi masyarakat lampung

c. Sebagai acuan dalam meningkatkan kemampuan Bahasa Lampung.

\subsubsection{Manfaat Penelitian}

a. Memberikan kemudahan bagi masyarakat pelajar dalam mengikuti materi pelajaran bahasa daerah yang saat ini menjadi salah satu muatan lokal dalam kegiatan belajar mengajar

b. Membantu masyarakat umum dalam mempelajari bahasa daerahnya melalui handphone seluler yang fleksibel dan mudah dibawa kemana saja.

c. Memberikan sumbangan bagi pemerintah daerah dalamBukan hanya bagifreelance writer, tetapi juga upaya melestarikan budaya daerah yang saat ini hampiruntuk freelancer di bidang lain. Selain lebih tak diperhatikan.

\section{LANDASAN TEORI \\ 2.1 Landasan Teori \\ 2.1.1 Definisi Teknologi Android}

Teknologi android adalah sistem operasi yang berbasis Linux untuk telepon seluler seperti telepon pintar dan komputer tablet. Android menyediakan platform terbuka bagi para pengembang untuk menciptakan aplikasi mereka sendiri untuk digunakan oleh bermacam peranti bergerak. Awalnya, Google Inc. membeli Android Inc., pendatang baru yang membuat peranti lunak untuk ponsel (Wikipedia).Selain sebagai media komunikasi dalam bentuk panggilan suara ataupun pesan singkat, dalam perkembangannya merupakan media yang mampu dilengkapi dengan berbagai program aplikasi tambahan untuk kemudahan pengguna. Implementasi Teknologi android adalah memanfaatkan suatu peralatan yang Mobile seperti handphone, tablet pc, dan lainnya. Salah satu bentuk pemanfaatan dari teknologi handphone tersebut adalah tentang pelayanan kesehatan dalam bentuk diagnosa penyakit. Diagnosis penyakit yang umum dilakukan untuk membantu pengguna dalam penanganan dan deteksi dini akan penyakit tersebut. Sehingga pelayanan kesehatan dapat lebih cepat dilakukan. Membangun aplikasinya menggunakan Android Application dengan implementasinyadapat berupa perangkat handphones yang tidak memberatkan memori, maka aplikasi ini dapat dibuat. Android Pemgroman Aplikasi Mobile Smartphone dan Tablet $P C$, Bandung, Informatika (Safaat, Nazrudin. 2011)

\subsubsection{Manfaat Kamus Bahasa Lampung berbasis android}

Terdapat beberapa manfaat penggunaan kamus,

diantaranya adalah:

a. Menambah dan mengembangkan perbendaharaan kata Tidak hanya kata per kata, melainkan juga kalimat, klausa, frasa, dan bahkan peribahasa.

b. Merangsang4 skill utama Saat menyaksikan film, meski tidak di sadari, Anda tengah mengasah 4skill utama dalam penguasaan bahasa. Listening (menyimak pemilihan, pengucapan, dan intonasi kata-kata), writing (saat menuliskan apa yang disimak - meski tidak tahu cara pengejaan suatu istilah dengan tepat, otak akan terangsang untuk mencari padanan ejaan yang sesuai), reading (saat membaca kembali kata-kata yang sudah di tulis - menuliskan dan membaca kembali sesuatu yang di anggap penting mampu membuat lebih mengingat dan memahami hal bersangkutan), dan speaking (saat menggunakannya dalam percakapan nyata — atau paling tidak saat melafalkannya).

\subsection{3 .Membantu Anda dalam menulis} mempermudah Anda dalam membuat tulisan (bagifreelance writer), perbendaharaan kata yang kaya juga membantu Anda dalam berkomunikasi dengan klien maupun calon klien asing dengan tidak melulu menggunakan istilah yang sama dan monoton. Memang bukan jaminan langsung mendapatkan proyek, tapi setidaknya pihak terkait tidak akan bosan dengan istilah "I think" atau "I can" yang terusmenerus Anda tulisdan/atau ucapkan. Kamus berguna membantu para pemakai untuk mengenal kata-kata baru berikut maknanya. Selain menerangkan makna kata, kamus juga memuat cara-cara mengucapkan kata tersebut, menerangkan asal kata serta memberikan contoh contoh penggunaannya dalam masyarakat Sedangkan Dr. Hamid Shadik Qatibi memandang kata kamus merupakan sinonim dari kata mu'jam dan memiliki fungsi-fungsi sebagai berikut: 
1. Menemukan makna sebuah kata

2. Menetapkan palafalan dan cara Menetapkan ejaan

3. Menelusuri asal asul sebuah kata Membedakan antara kata yang tak lazim dan tak terpakai serta menjelaskan kata- kata yang murni dan serapan

4. Mengetahui sinonim dan antonym

5. Penggunaan kata-kata sastra dan peribahasa Pengetahuan yang bersifat ensiklopedia.(http://togaparuhum.blogspot.com)

\subsubsection{Definisi Basis Data (Database)}

Suatu kumpulan dari item data yang saling berhubungan satu dengan yang lainnya yang diorganisasikan berdasarkan sebuah skema atau struktur tertentu. Tersimpan di hardware komputer dan dengan software untuk melakukan manipulasi untuk kegunaan tertentu, (Sutanta, 2004)

\subsubsection{Metode Pengembangan Sistem}

Dalam melakukan pengembangan sistem informasi, terdapat berbagai metodologi yang dapat digunakan. Setiap metodologi akan menguraikan tahapan-tahapan dan aturan dalam pengembangan sistem informasi.

Adapun tujuan dari semua metodologi tersebut adalah keberhasilan mengembangkan sistem informasi dengan tepat waktu, tepat biaya dan sesuai kebutuhan yang diharapkan pengguna.

Dari beberapa model yang sudah dikenal, metodologi dengan teknik waterfall adalah yang paling mudah dan sering digunakan. Tahapan pengembangan dengan teknik waterfall dilakukan secara berurutan seperti digambarkan pada gambar 1 (Sommervile,ian,2001).

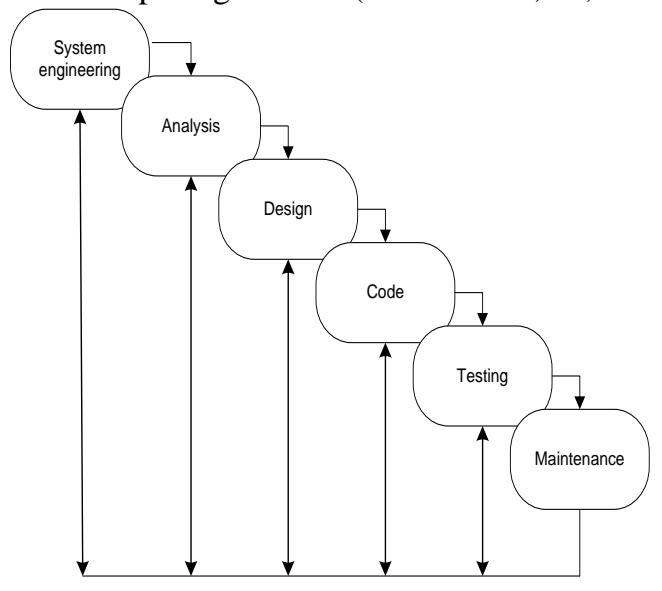

Gambar 1. Tahapan Waterfall

Tahapan ini dilakukan secara berurutan seperti diuraikan berikut ini :

a. Analisys

Tahapan analisis meliputi analisa sistem dan analisa persyaratan. dilakukan untuk mendapatkan gambaran yang meluas pada lingkup sistem, sedangkan pada tahap analisis persyaratan difokuskan lebih terarah ke software. Analisis persyaratan berusaha mengetahui aspekyang harus dipenuhi oleh perangkat lunak yang dihasilkan. Tahapan ini banyak melibatkan pemakai dan pengembang sistem.

\section{b. Design}

Tahapan perancangan bertujuan menerjemahkan persyaratan menjadi suatu bentuk representasi yang dapat dievaluasi, meliputi pemodelan usulan pengembangan system sebelum tahap coding dilakukan.

c. Coding

Merupakan tahap penerjemahan rancangan ke dalam bentuk yang dapat dimengerti komputer. Pada tahap ini model yang telah dibuat diterjemahkan dalam bentuk instruksi-instruksi menggunakan perangkat lunak pemrograman (software language) dan perangkat lunak pengelola database yang sesuai dengan spesifikasi yang dibutuhkan.

d. Testing

Tahap ini berfokus pada pengujian rincian logika software. Pengujian bertujuan mengungkapkan dan menghilangkan kesalahan-kesalahan yang ada sehingga software bekerja sesuai dengan spesifikasi kebutuhan pemakai (user requirement) yang telah didefinisikan.

\section{e. Maintenance}

Tahap pemeliharaan meliputi kegiatan-kegiatan koreksi kesalahan dan penyesuaian sofware terhadap perubahan lingkungan siatem.

\subsubsection{Alat Bantu Pengembangan Sistem}

Alat bantu (tools) yang digunakan dalam memodelkan pengembangan sistem antara lain Data Flow Diagram (DFD), Entity Relationship Diagram, normalisasi dan Flowchart program (Sutanta,2006).

\subsubsection{Perangkat Lunak Pendukung}

Pada tahap coding dibutuhkan perangkat lunak pendukung. Perangkat lunak yang dimaksud diantaranya adalah perangkat lunak bahasa dan perangkat lunak manajemen Database. Salah satu Perangkat lunak bahasa yang dapat digunakan adalah dan MySQL.

\subsubsection{Mengenal MySQL}

MySQL adalah sebuah system manajemen database bersifat open source. MySQL adalah pasangan serasi dari PHP. MySQL dibuat dan dikembangkan oleh MySQL AB yang berada di Swedia. MySQL dapat digunakan untuk membuat dan mengelola database beserta isinya. MySQL dapat dimanfaatkan untuk menambah, mengubah, dan menghapus data yang berada di dalam database.

MySQL merupakan system manajemen database yang bersifat relational. Artinya data-data yang dikelola dalam database akan diletakan pada beberapa table yang terpisah sehingga manipulasi akan menjadi lebih cepat. MySQL dapat digunakan untuk mengelola database mulai dari yang kecil sampai dengan sangat besar. MySQL juga dapat dijalankan perintah-perintah Structured Query Language ( $S Q L$ ) untuk mengelola database-database relational yang ada di dalamnya. 


\subsubsection{Software PeMrograman ECliPSE}

Eclipse awalnya dikembangkan oleh IBM untuk menggantikan perangkat lunak IBM Visual Age for Java 4.0. Produk ini diluncurkan oleh IBM pada tanggal 5 November 2001, yang menginvestasikan sebanyak US\$ 40 juta $^{[1]}$ untuk pengembangannya. Semenjak itu konsursium Eclipse Foundation mengambil alih untuk pengembangan Eclipse lebih lanjut dan pengaturan organisasinya. Secara standar Eclipse selalu dilengkapi dengan JDT (Java Development Tools), plug-in yang membuat Eclipse kompatibel untuk mengembangkan program Java, dan PDE (Plug-in Development Environment) untuk mengembangkan plug-in baru. Eclipse beserta plug-in-nya diimplementasikan dalam bahasa pemrograman Java.

Konsep Eclipse adalah IDE yang terbuka (open), mudah diperluas (extensible) untuk apa saja, dan tidak untuk sesuatu yang spesifik ${ }^{[2]}$. Jadi, Eclipse tidak saja untuk mengembangkan program Java, akan tetapi dapat digunakan untuk berbagai macam keperluan, cukup dengan menginstal plug-in yang dibutuhkan. Apabila ingin mengembangkan program $\mathrm{C} / \mathrm{C}++$ terdapat pluginCDT $(\mathrm{C} / \mathrm{C}++$ Development Tools $)$. Selain itu, pengembangan secara visual bukan hal yang tidak mungkin oleh Eclipse, plug-inUML2 tersedia untuk membuat diagram UML. Dengan menggunakan PDE setiap orang bisa membuat plug-in sesuai dengan keinginannya. Salah satu situs yang menawarkan plugin secara gratis seperti Eclipse downloads by project. Selain itu, kelebihan dari Eclipse yang membuatnya populer adalah kemampuannya untuk dapat dikembangkan oleh pengguna dengan komponen yang dinamakan plug-in.

Elipse+AVR plugin, dengan tambahan plugin tersebut kita dapat memprogram mikrokontroler AVR menggunakan IDE ini, selain itu keuntungan menggunakan eclipse ialah dapat bekerja di berbagai sistem operasi seperti Microsoft Windows, Linux, Solaris, AIX, HP-UX dan Mac OS X. ( ttp://id.wikipedia.org/wiki/Eclipse)

\section{METODOLOGI PENELITIAN}

Metodologi adalah ilmu tentang kerangka kerja
untuk melaksanakan penelitian bersistem,sekumpulan peraturan kegiatan dari prosedur yang digunakan oleh pelaku suatu disiplin ilmu,studi analitis teoritis mengenai suatu cara/metode;atau cabang ilmu logika yang berkaitan dengan prinsip umum pembentukan pengetahuan (knowledge). Peneliti membuat penelitian ini dengan menggunakan metode deskritif, yaitu penelitian yang berusaha mendiskripsikan suatu gejala, peristiwa kejadian yang terjadi saat sekarang. Penelitian deskritif memusatkan perhatian pada masalah aktual sebagaimana adanya pada saat penelitian berlangsung penelitian deskrif sesuai karakteristiknya memiliki langkah-langkah tertentu dalam pelaksanaanya. Langkah-langkah ini sebagai berikut :
Diawali dengan adanya masalah, menentukan jenis informasi yang diperlukan, menentukan prosedur pengumpulan data melalui observasi atau pengamatan pengolahan informasi atau data dan menarik kesimpulan penelitian. (Noor Juliansyah,2011).objek yang diteliti yaiu Aplikasi visualisasi kamus bahasa lampung berbasis android.

\subsection{Teknik Pengumpulan Data}

Teknik pengumpulan data yang digunakan dalam penelitian ini adalah dengan melakukan studi pustaka (library research) dan studi lapangan (field reserch).

\section{a.Studi Pustaka (library research)}

untuk mendukung penelitian ilmiah ini,peneliti melakukan pengumpulan data melalui panduan buku referensi dan literatur lainnya yang berhubungan dengan pengetahuan teoritis mengenai masalah yang sedang diteliti. Yang kemudian dijadikan data untuk diolah lebih lanjut.

\section{b.Studi Lapangan (field reseaarch)}

Peneliti mengadakan studi lapangan studi lapangan dengan mengadakan penelitian langsung menemui tokoh tokoh adat daerah lampung yang dijadikan sebagai sumber informasi kata dan terutama cara pengucapannya kata daerah yang benar (visualisasi).dengan menggunakan metode sebagai berikut :

\section{Wawancara}

Wawancara merupakan salah salah satu teknik pengumpulan data yang dilakukan dengan berhadapan secara langsung dengan yang diwawancarai tetapi dapat juga diberikan daftar pertanyaan dahulu untuk dijawab pada kesempatan lain. Wawancara merupakan alat re-checking atau pembuktian terhadap informasi atau keterangan yang diperoleh sebelumnya (Noor,Juliansyah,2011) peneliti melakukan wawancara dengan tokoh tokoh adat lampung. Pada wawancara yang dilakukan peneliti, peneliti menanyakan tentang beberapa hal penting yang menunjang untuk penelitin ini

1.Mengenai sejarah bahasa Lampung

2.Mengenai Dialek bahasa lampung

3.Mengenai Pengucapan kata bahasa lampung

4.Mengenai pengunaan imbuhan dalam bahasa lampung

\section{Survey}

Survey, dilakukan untuk mengumpulkan informasi tentang : pengelompokan bahasa daerah di Lampung, mencari tokoh-tokoh adat daerah lampung yang dapat dijadikan sebagai sumber informasi kata dan terutama cara pengucapan kata daerah yang benar (visualisasinya).

\section{Observasi}

Teknik ini menuntut adanya pengamatan dari penelitian baik secara langsung maupun tidak langsung terhadap objek penelitian instrument yang dapat digunakan yaitu lembar pengamatan, panduan pengamatan, beberapa informasi yang diperoleh dari hasil observasi antara lain : ruang (tempat), pelaku,kegiatan 
objek,pembuatan,kejadian,atauperistiwa, waktu,dan perasaan .(Noor,juliansyah,2011)

\section{Literatur}

Studi literature, yaitu dengan mempelajari pengelompokan bahasa lampung dan mengumpulkan data bahasa lampung yang akan dijadikan sebagai basis data dalam pembuatan kamus. Selain itu mempersiapkan software-software berbasis android yang dibutuhkan dalam pelaksanaan rancang bangun aplikasi kamus bahasa lampung.

\subsection{Analsis Sistem yang berjalan}

Melakukan analisys : pada tahap ini fungsi-fungsi yang dibutuhkan (Functional Requirements) didefinisikan. Fungsi-fungsi tersebut dapat digambarkan sbb:

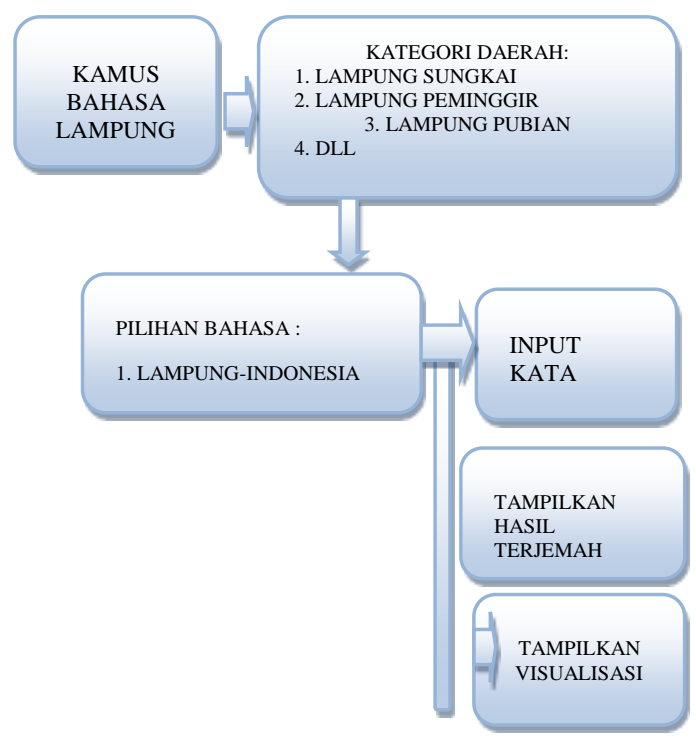

Gambar 2. Menu Utama kamus Bahasa Lampung berbasis android

Melakukan desain sistem kamus bahasa lampung berbasis android. Desain yang dilakukan meliputi :

1. Desain input/output : membuat tampilan yang akan dihasilkan dalam kamus diantaranya terdiri dari menu tampilan awal, menu pilihan bahasa, menu input kata, menu tampilan terjemahan dan menu tampilkan suara.

2. Desain proses/ aliran data : proses ini diuraikan menggunakan Diagram Context

3. Desain data base : Menggambarkan data-data yang akan disimpan didalam data base dan keterkaitan antar data tersebut, Digambarkan menggunakan Entity Relationship Diagram, selanjutnya dilakukan proses normalisasi.

4. Desain Logika program : Flowchart program digunakan untuk menggambarkan alur logika dari menu dan sub menu yang disediakan.

Melakukan Coding.

Perangkat lunak bahasa yang digunakan dalam pembuatan kamus bahasa daerah ini adalah bahasa pemrograman eclipse
Melakukan Testing untuk menguji kesesuaian system yang dihasilkan denganuser requirement yang telah didefinisikan pada tahap analisy

\section{Pembuatan Perangkat lunak}

Pembangunan program sistem kamus bahasa Lampung ini dikembangkan menggunakan perangkat lunak pendukung yaitu perangkat lunak bahasa dan perangkat lunak database. Perangkat lunak dikembangkan dalam bentuk modul-modul (fungsifungsi).

\section{PEMBAHASAN}

Tahapan yang akan dilakukan dalam penelitian ini terdiri dari : tahap analisis, , perancangan, pembuatan perangkat lunak dan testing. Aplikasi ini menghasilkan kemampuan untuk menterjemahkan kata dari dua sumber input, yaitu kata bersumber bahasa Indonesia dan sumber bahasa Lampung. Kata bersumber bahasa Indonesia diterjemahkan ke bahasa Lampung, sebaliknya input yang bersumber bahasa Lampung akan diterjemahkan ke bahasa Indonesia. Selain menampilkan hasil terjemahan aplikasi ini juga memiliki kemampuan untuk menampilkan suara. Tampilan suara dapat diperoleh dengan meng klik kata hasil terjemahan yang dihasilkan

\subsection{Perancangan Interface (Input-output)}

Output yang dihasilkan dari aplikasi kamus bahasa lampung ini terdiri dari: tampilan menu utama, tampilan menu update, tampilan input untuk pilihan sumber bahasa Indonesia dan sumber bahasa lampung, tampilan output untuk hasil terjemahan bahasa indonesia dan hasil terjemahan bahasa lampung.

\subsection{Perancangan Data Base}

Data Base pendukung dalam sistem kamus bahasa Lampung ini terdiri dari dua tabel yaitu : tabel user, tabel sinonim, tabel jurnal dan tabel token. Secara terinci ditunjukkan pada gambar berikut ini :

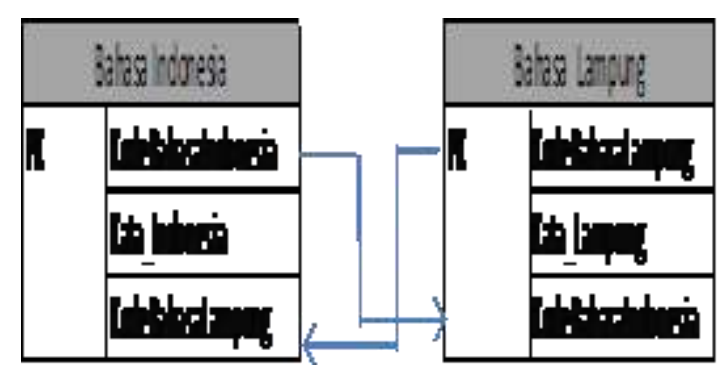

Gambar 3. Relasi Tabel

\section{Logika Program}




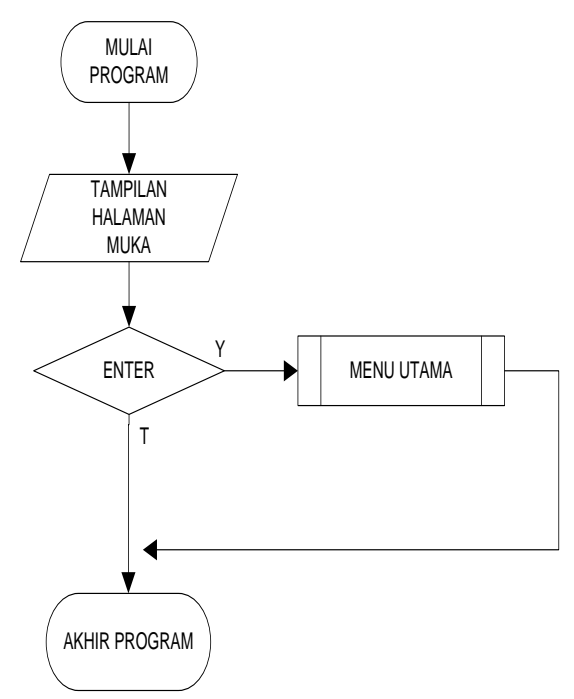

Gambar 4. Logika Program

\subsection{Tampilan Hasil}

4.4. 1.Halaman awal ketika diakses

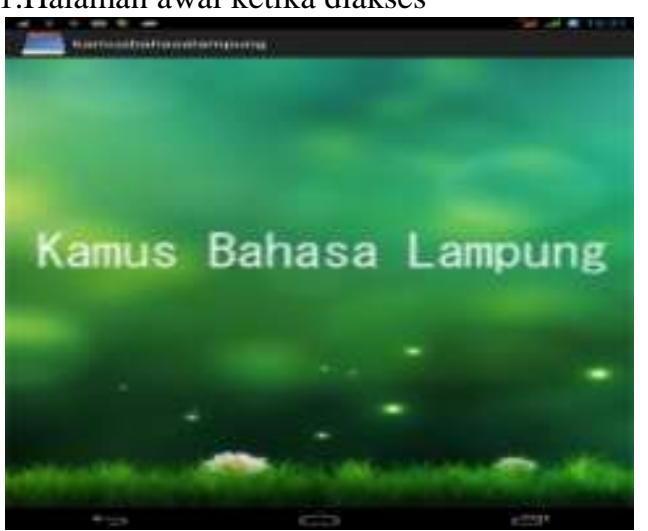

Gambar 5. Tampilan Awal

4.4.2.pada halaman pertama maka pengguna dalam hail ini adalah admin di wajibkan untuk memasukan nama pengguna dan kata sandinya

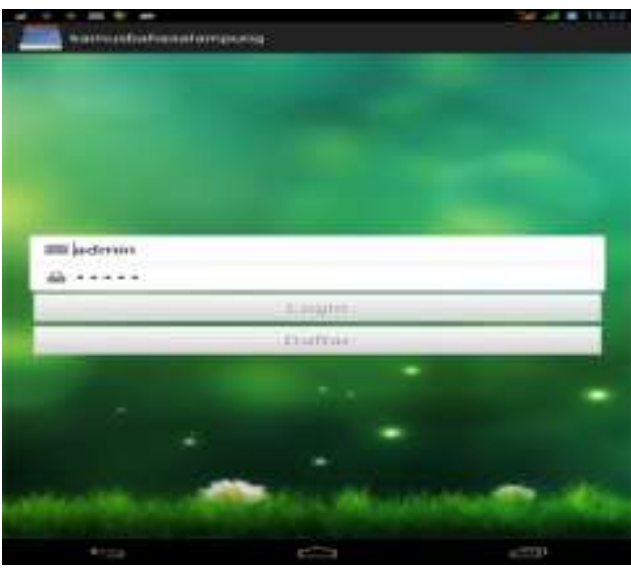

Gambar 6.. Menu login
Setelah login berhasil maka akan muncul tampilan beranda atau menu halaman utama

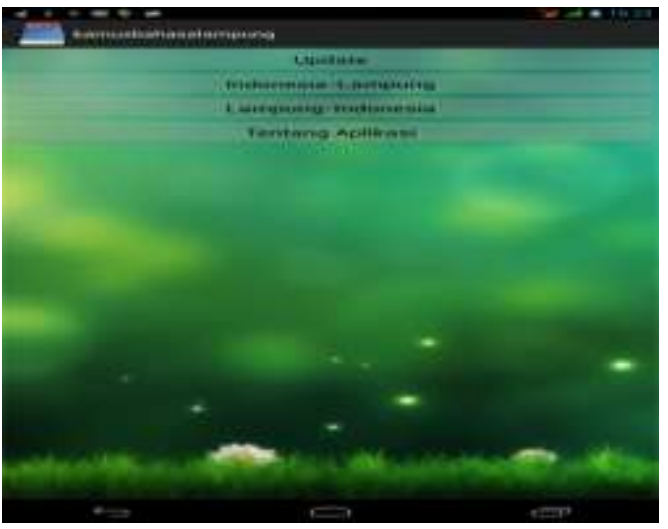

Gambar 7.Tampilan Menu Pilihan.

\subsubsection{Tampilan Input Bahasa Indonesia}

Menu ini digunakan untuk mengkonversi dari bahasa indonesia ke bahasa lampung

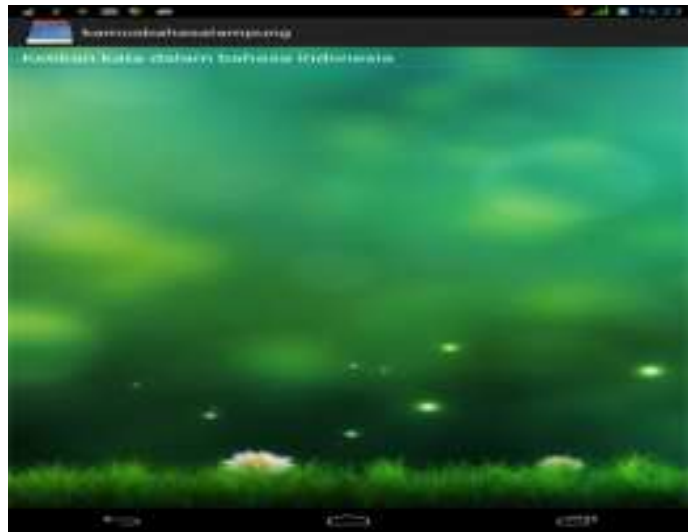

Gambar 8.Tampilan Input Bahasa Indonesia

\subsubsection{Tampilan Hasil Bahasa Lampung}

Menu ini di gunakan untuk mengkonversi bahasa lampung ke bahasa indonesia

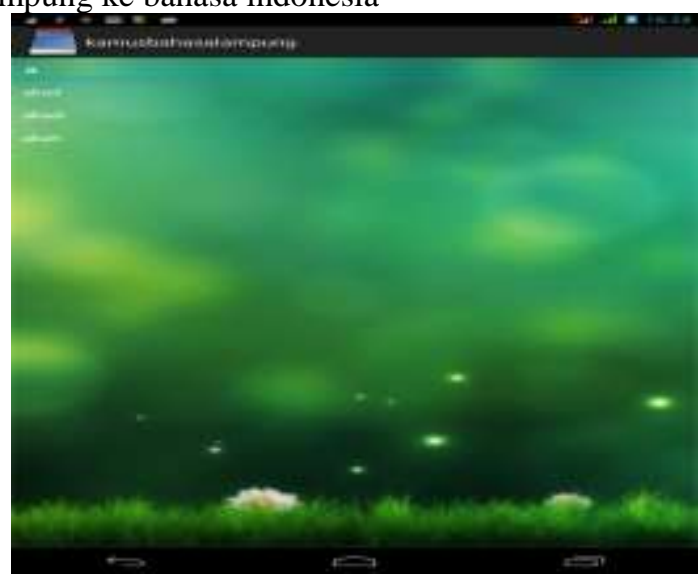

Gambar 9. Tampilan Hasil Terjemahan Bahasa Lampung

\subsubsection{Tampilan Menu Pilihan}

4.4.6. Tampilan Untuk Menampilkan Suara 
Menu ini digunakan untuk mendengarkan suara bagaimana cara membaca yang benar dari hasil konversi diatas

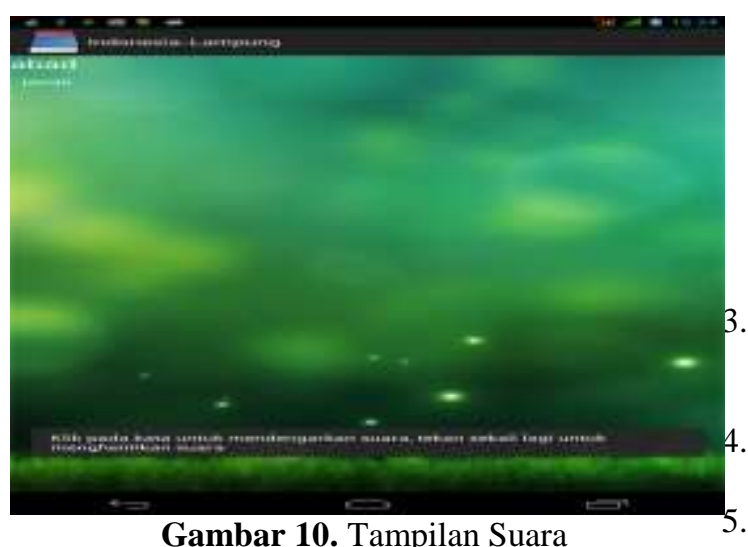

Gambar 10. Tampilan Suara

\subsubsection{Tampilan Input Bahasa Lampung}

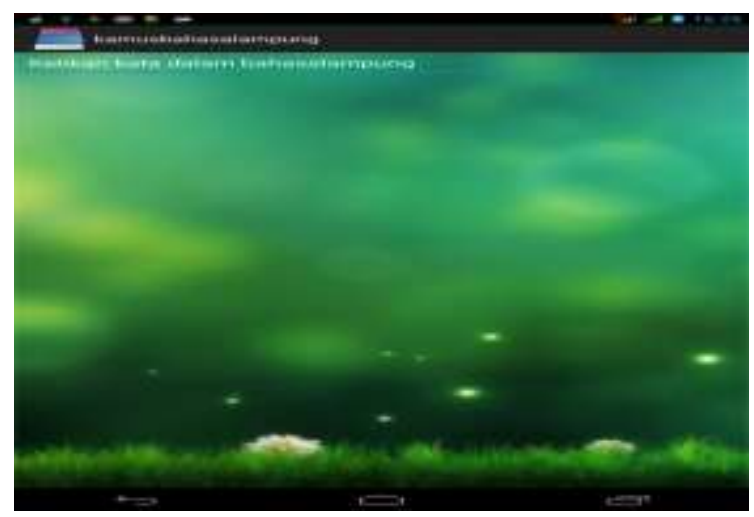

Gambar 11. Tampilan Input Bahasa Lampung

\subsubsection{Tampilan Hasil Terjemahan bahasa} Indonesia

Halaman ini menampilkan hasil dari terjemahan

bahasa indonesia

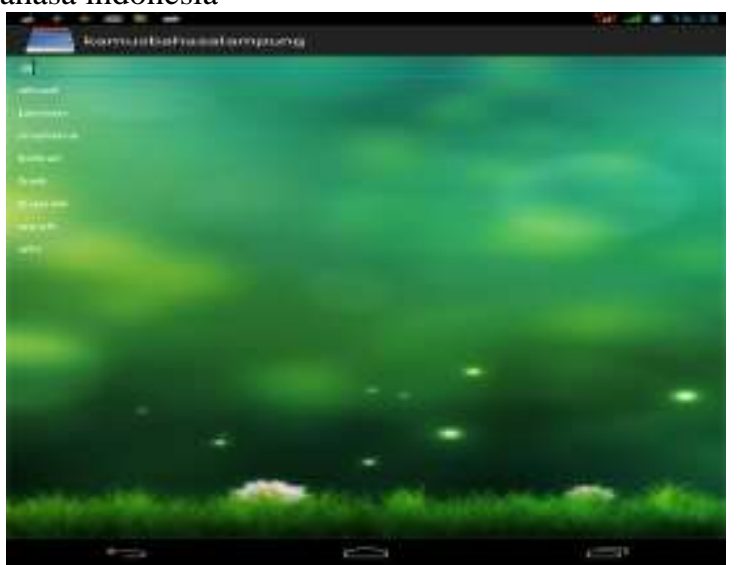

Gambar 12. Tampilan Hasil Terjemahan Bahasa Indonesia

6.

\section{KESIMPULAN DAN SARAN}

\subsection{Kesimpulan}

Dari rancangan yang dibuat maka dapat disimpulkan sebagai berikut :

1. Berdasarkan survey dan analisa di peroleh bahwa Bahasa Lampung terdiri dari beberapa kelompok yaitu : Menggala,Pubian,Pesisir, dan Sungkai.

Penelitian ini mengacu pada perbendaharaan lampung sungkai

2. Desain input-output menyediakan dua alternatif pilihan : Lampung-Indonesia dan Indonesia Lampung.

Hasil Terjemahan akan mengacu pada dua tabel database yaitu tabel bahasa Indonesia dan Bahasa Lampung.

Tampilan suara dapat diperoleh cukup dengan mengklik kata hasil terjemahan.

Aplikasi berbasis android ini dapat digunakan menggunakan Handphone berbasis android.

\subsection{SARAN}

Penyempurnaan masih perlu dilakukan terhadap kelengkapan isi data base sehingga dapat mengadopsi kata secara lebih lengkap. Selain dari kelengkapan konten pengembangan masih perlu dilakukan terhadap beberapa dialek lain yang belum diadopsi dalam penelitian ini

\section{DAFTAR PUSTAKA}

[1] Arief, M. rudyanto, 2011, Pemrograman WebDinamis Menggunakan PHP dan MySQL, Yogjakarta

[2] (http://sidiqideas.wordpress.com/2012/03/26/manf aat-kamus/), diakses tgl 14 Desember 2013 jam 10.30)

[3] Juliansyah Noor, S .2011 Metodologi Penelitian :Skripsi,Tesis,Disertasi, dan karya ilmiah kencana

[4] Peraturan Gubernur Lampung No. 4 Tahun 2011 tentang Pengembangan, Pelestarian Bahasa Lampung dan Aksara Lampung, lamppost.co.id

[5] Perda Provinsi Lampung No.2 Tahun 2008 pasal 8 poin (e).

[6] Sommerville, Ian., 2001, Software Engineering .6th . Addison Wesley.

[7] Sutanta, Eddy, 2004, system Informasi Manajemen, Graha Ilmu: Yogyakarta

[8] Safaat, Nazrudin. 2011. Android Pemgroman Aplikasi Mobile Smartphone dan Tablet PC, Bandung, Informatika

[9] Wikipedia, 2012, Sistem Operasi Android (online), (Wikipedia.org diakses tgl 13 Desember 2013 jam 09.30. 


\section{Redaksi :}

Pusat Study Teknologi Informasi (PSTI). Gedung Business Center Lt 2 J. Zainal Abidin No. 26 Bandar Lampung Telp. 0721 - 774626 